\title{
Neuronal intermediate filaments in the developing tongue of the frog Rana esculenta
}

\author{
K. Zuwala, ${ }^{1}$ F. Merigo, ${ }^{2}$ C. Zancanaro ${ }^{2}$ \\ ${ }^{1}$ Department of Comparative Anatomy, Jagiellonian University, Kraków, Poland; 'Department of \\ Morphological and Biomedical Sciences, Section of Human Anatomy and Histology, University of Verona, \\ Verona, Italy
}

(C)2004, European Journal of Histochemistry

The expression of several neuronal intermediate filament (NIF) proteins was investigated in the tongue of metamorphosing tadpoles (stage 38-45 of Gosner) and in adult individuals of the frog, Rana esculenta by means of immunohistochemistry. Results showed that nerve fibres at early stages of tongue development expressed peripherin (a NIF protein usually found in differentiating neurones) as well as the light- and medium molecular weight NIF polypeptide subunits (NF-L and NF-M, respectively); in the adult frog, peripherin was still found in nerve fibres reaching the fungiform papilla together with NF-M, but NF-L immunoreactivity was absent therein. Clusters of epithelial cells expressing peripherin were found in the early developing tongue before differentiation of taste organs, and NF-L and NF-H immunoreactivities were present in basal (Merkel) cells of the adult frog taste disc. Results indicate that neurones innervating the adult frog's taste disc maintain a certain plasticity in their cytoskeleton and that neuronal-like cells are present in the undifferentiated and differentiated tongue epithelium possibly playing a role in the developing and mature taste organ.

Key words: green frog, taste disc, neurofilaments, immunohistochemistry, basal cell, peripherin

Correspondence: Dr. Krystyna Zuwala, Department of Comparative Anatomy, Institute of Zoology, Jagiellonian University, 30-060 Kraków, Ingardena 6, Poland.

Phone: international +48.26632653. Fax: international +48.12.6343716.E-mail: zuwa@zuk.iz.uj.edu.pl

Paper accepted on November 17, 2003

European Journal of Histochemistry 2004; vol. 48 issue 2 [Apr-Jun]: 121-128
$\mathrm{R}$ ecent structural study of the gustatory organs in Anura have essentially been conducted along two lines of research: (1) immunohistochemical and ultrastructural investigation of taste discs (TD) in adult individuals (Gioglio et al. 1988; Toyoshima et al. 1988; Kuramoto 1988; Zancanaro et al. 1990; Witt 1993; Sbarbati et al. 1993), reviewed in Osculati, Sbarbati 1995, and (2) morphological studies of the gustatory organs during ontogenesis (Nomura et al. 1979a, b; Zuwala 1991, 2002a, b; Zuwala et al. 1991, 1997, 2000; Zuwala et al. 2002).

Detailed follow up of morphological changes ( $L M$, SEM, TEM) in the developing taste discs of Anura species belonging to different families (Zuwala 1991, 2002a, b; Zuwala et al. 1991, 1997, 2000) revealed a general developmental pattern i.e., formation of taste discs - the second generation of gustatory organs - is closely linked to the process of metamorphosis and the final differentiation of the sensory epithelium of lingual taste discs directly correlates with the development of fungiform papillae and the tongue itself. However, immunohistochemical data concerning the development of gustatory organs are generally scarce and mainly concern the localisation of neuropeptides (Wakisaka et al. 1996; Kusakabe et al. 1996; Witt et al. 2000; Chou et al. 2001; Zuwala 2002a).

Neurofilaments (NIF) are important cytoplasmic structural constituents of nerve cells, playing a role in the organisation of the cytoskeleton, as well as in axonal and dendritic transport. NIF are composed of three polypeptide subunits of low (NF-L), medium (NF-M), and high (NF-H) molecular weight, which are expressed sequentially during development: NF$L$ and NF-M appear during neurite differentiation, NF-H is found as the cytoskeleton is stabilized (Willard et al. 1983; Carden et al. 1987; Szaro et al. 1989). NF-L has been observed in all vertebrate classes (Shecket et al. 1980; Shaw et al. 1984; Walker et al. 1985). Distinct H and M polypeptides 
Table 1. Polyclonal antibodies used in immunohistochemical staining.

\begin{tabular}{lcc}
\hline \hline Antibody & Abbreviation & Dilution \\
\hline Peripherin & Peripherin & $1: 1600-1: 3200$ \\
Neurofilament $68 \mathrm{kDa}$ & NF-L & $1: 500-1: 1000$ \\
Neurofilament $150 \mathrm{kDa}$ & $\mathrm{NF}-\mathrm{M}$ & $1: 400-1: 800$ \\
Neurofilament $200 \mathrm{kDa}$ & $\mathrm{NF}-\mathrm{H}$ & $1: 500-1: 1000$ \\
\hline
\end{tabular}

have been found in birds, whereas reptilian NF contain only one high molecular weight subunit which cross-reacts with both $\mathrm{H}$ and $\mathrm{M}$ from mammals. Using antibodies reacting with the phosphorylated epitopes to the bovine $\mathrm{H}$ and $\mathrm{M}$ subunits, Mencarelli et al. (1987) showed the presence in the frog spinal cord of two polypeptides cross reacting with either of the $\mathrm{H}$ or $\mathrm{M}$ subunit from mammals, thus confirming previous evidence (Lasek et al. 1985). The presence of NF-L cross-reacting with the mammalian antigen was shown by Szaro and Gainer (1988) in post-metamorphic Xenopus laevis neurones. In the same work Szaro and Gainer demonstrated the presence of the three NF in the central nervous system of metamorphic tadpoles (stage 42). In order to better characterise the developmental patterns of amphibian taste organs in relation with their adult counterpart, the work reported herein investigated the timing of appearance of NIF proteins NF-L, NF-M , and $\mathrm{NF}-\mathrm{H}$ at consecutive stages of fungiform papillae formation in the developing lingual fold of Rana esculenta tadpoles and in adult individuals. Moreover, the expression of peripherin (Portier et al. 1983) [called XIF3 in amphibians (Gervasi et al. 2000)], a different NIF protein found in differentiating and in certain mature neurones (Troy et al. 1990a) was investigated in the same material.

\section{Materials and Methods}

\section{Tissue preparation}

Tadpoles of Rana esculenta at different Gosners' (1960) developmental stages: 38, 40, 41, 42, 43, 44,45 and adult individuals were used in the present study. Animals were anaesthetized with $0.1 \%$ tricaine (3-aminobenzoic acid ethyl ester) in tap water. Tongues were excised and fixed for $2 \mathrm{~h}$ in $4 \%$ paraformaldehyde dissolved in $0.1 \mathrm{M}$ phosphate buffer $\mathrm{pH} 7.4$ at $4^{\circ} \mathrm{C}$. After rinsing in $0.1 \mathrm{M}$ phosphate buffer, tissues were exposed to $0.5 \mathrm{M} \mathrm{NH}_{4} \mathrm{Cl}$ to block free aldehydes. Specimens were then dehydrated through an ascending series of ethanol, transferred to xylene and embedded in paraffin wax $\left(56^{\circ} \mathrm{C}\right)$. Serial $7 \mu \mathrm{m}$-thick sections were cut on a rotative microtome (Leitz 1512, Germany), collected on polylysine-coated slides and dried overnight at $37^{\circ} \mathrm{C}$.

\section{Immunohistochemistry}

The primary polyclonal antibodies used in this study respectively recognize the following antigens: peripherin, $68 \mathrm{kDa}$ neurofilament protein (NF-L), $150 \mathrm{kDa}$ neurofilament protein (NF-M) and 200 $\mathrm{kDa}$ neurofilament protein (NF-H). All antibodies were obtained from a commercial source (Chemicon International Inc., Temecula, CA, USA); their working dilutions and abbreviation are summarized in Table 1. According to the manufacturer, the antiperipherin and the anti-NF-H antibody do not cross react with other neuronal intermediate filament proteins. The antisera to neurofilament subunit proteins recognize both the phosphorylated and non-phosphorylated forms; the cross-reactivity of the NF-L and the NF-M or NF-H antibodies is less than $2 \%$; the cross-reactivity of the NF-M and the NF-L or $\mathrm{NF}-\mathrm{H}$ antibodies is $0.4 \%$ and $0.6 \%$, respectively.

Immunohistochemical staining was performed using the avidin-biotin complex $(A B C)$ technique. Briefly, sections were deparaffinised and rehydrated through xylene and a descending ethanol series. Endogenous peroxidase was quenched by immersion in a solution of $0.3 \%$ hydrogen peroxide in methanol for 30 min. After washing in $0.05 \mathrm{M}$ Tris-HCL buffer $\mathrm{pH} 7.6$, sections were treated with $5 \%$ normal swine serum for $60 \mathrm{~min}$. Subsequently, the primary antibody was applied overnight at $4^{\circ} \mathrm{C}$. After three washes, sections were then reacted with biotinylated swine anti-rabbit immunoglobulins (DAKO, Milan, Italy), diluted 1:400, for 2 hours. The immunoreaction was detected using a Vectastain Elite $A B C$ kit (Vector, Burlingame, CA, USA), and then visualized by 3,3 diaminobenzidine tetrahydrocloride (Dako) for 5-10 min. Finally, sections were dehydrated, coverslipped with Entellan, and observed and photographed in an Olympus BX51 photomicroscope equipped with a KY-F58 LCD camera (JVC); images were acquired and stored using the Image-ProPlus software on a personal computer. Control sections were processed as above but omitting the primary antibodies; no immunostaining was observed in these sections. 

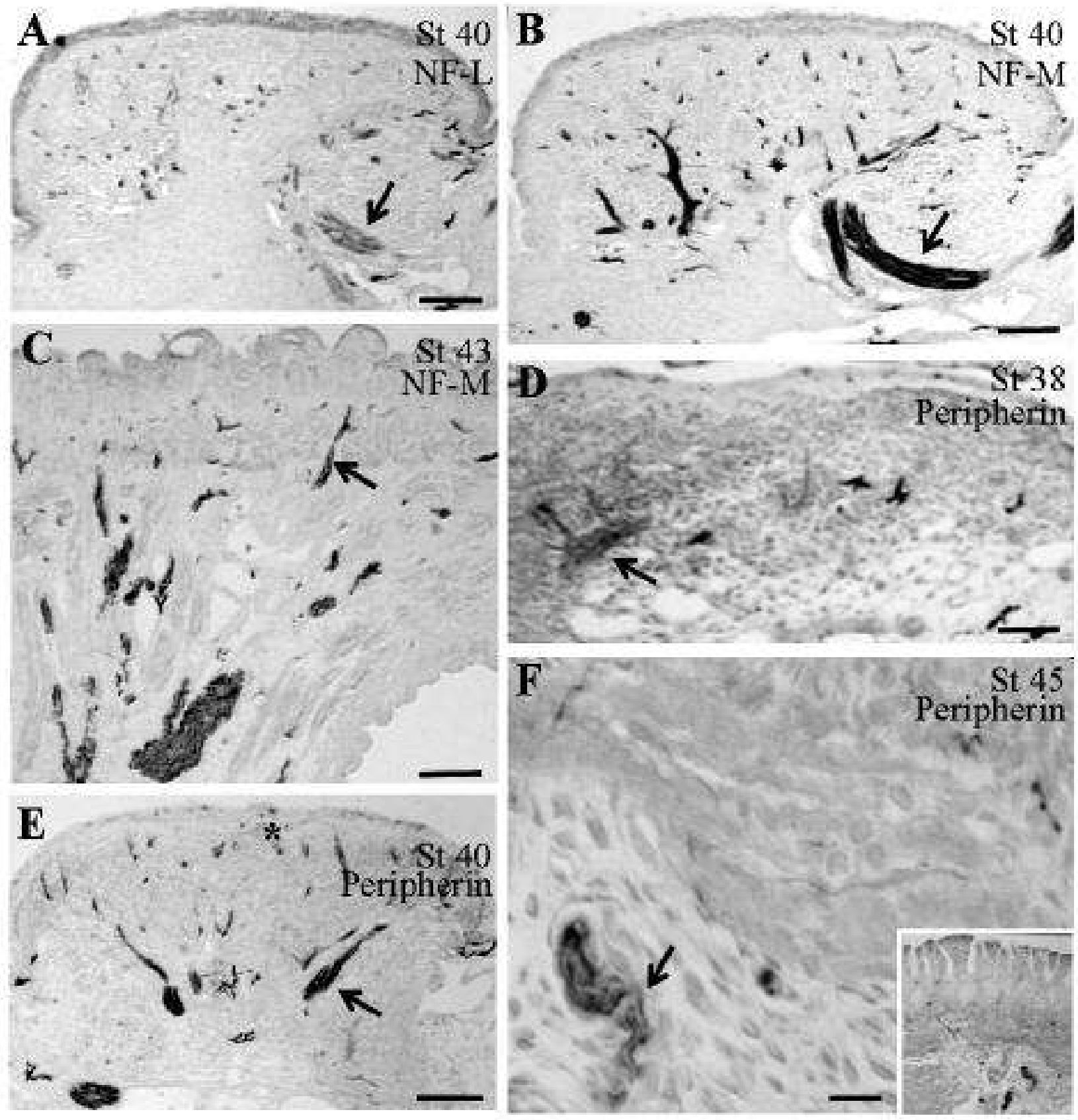

Figure 1. Expression of neuronal intermediate filaments in the body of the tongue of Rana esculenta tadpoles. St, developmental stage of Gosner; NF-L and NF-M, antibody to the light- and medium molecular weight subunit of filament triplet used for immunostaining. Arrow, immunoreactive nerve trunk. Asterisk, epithelial cell immunoreactive for peripherin. The inset (F) presents a low-power picture to show the localisation of the immunoreactive nerve trunk in the tongue. See also Table 2. Scale bar: A-E, $60 \mu \mathrm{m} ; \mathrm{F}, 10 \mu \mathrm{m}$.

\section{Results}

\section{NIF proteins in nerves of the body of the tongue (Table 2, Figure 1A-F)}

Immunoreactivity for NF-M and peripherin was found in nerve trunks of the body of the developing tongue from developmental stage 38 onwards with maximum intensity at stage 40 to 41 and 43 , respectively. Immunoreactivity for NF-L appeared therein at stage 40. Expression of the above NIF proteins in nerves of the body of the tongue persisted in the adult frog. NF-H immunoreactive fibres were never found in our material. 

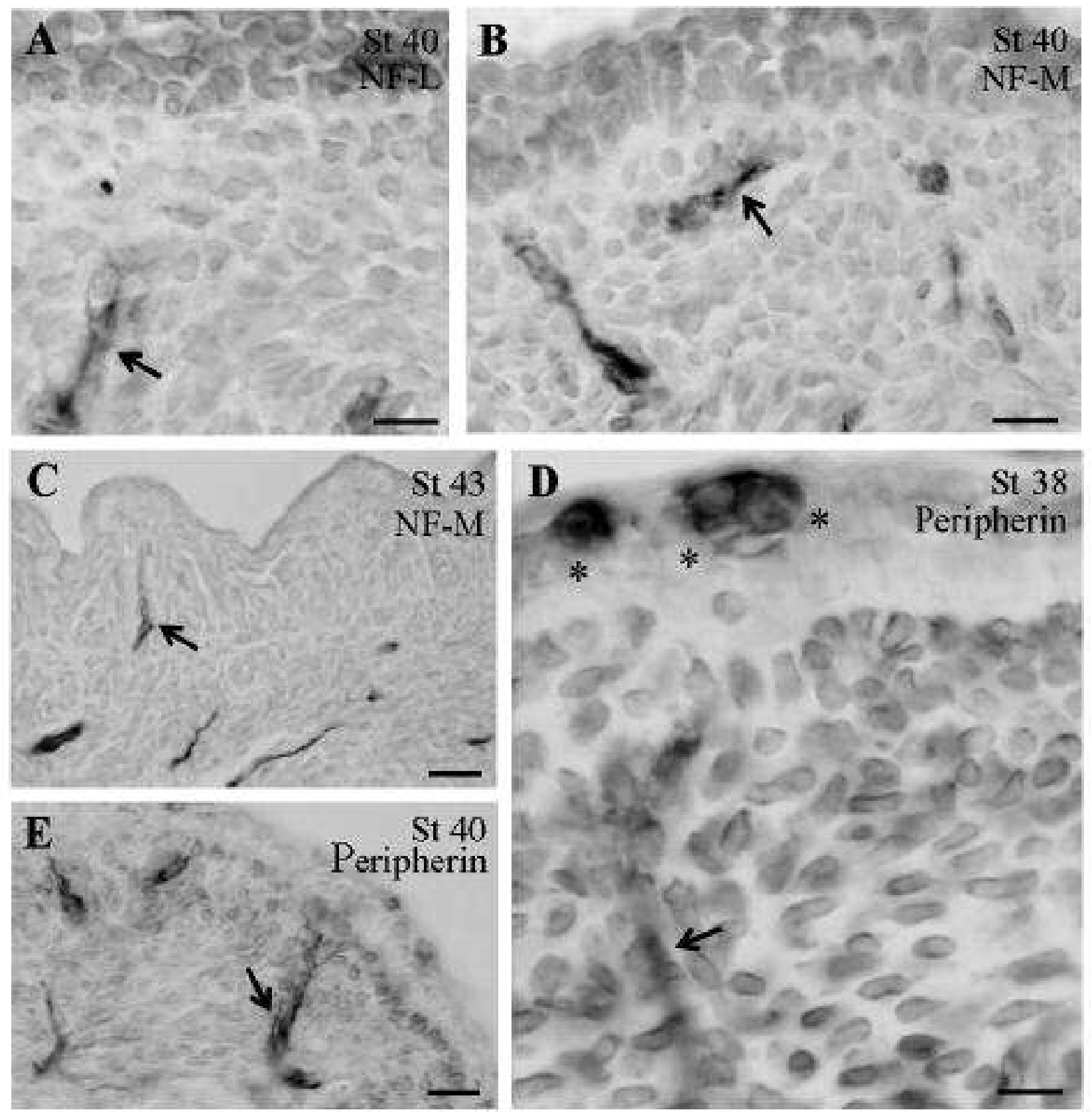

Figure 2. Distribution of immunoreactivity for different neuronal intermediate filaments in the sub/intra epithelial nerve fibres and epithelial cells of the tongue of Rana esculenta tadpoles. St, developmental stage of Gosner; NF-L and NF-M, antibody to the light- and medium molecular weight subunit of filament triplet used for immunostaining. Arrow, immunoreactive nerve fibres; asterisk, clusters of epithelial cells immunoreactive for peripherin. See also Table 3. Scale bar: $10 \mu \mathrm{m}$.

NIF proteins in epithelial cells and sub/intraepithelial nerve fibres of the tongue (Table 3; Figure 2A-E)

Some cells of the developing lingual epithelium expressed peripherin at stage 38 to 41 (see also Figure $1 \mathrm{E}$ ). Peripherin was also present in nerve fibres closely associated with the epithelium starting from stage 38 to the end of metamorphosis (see also Figure $\mathrm{IE}$ and $\mathrm{F}$ ) as well as in the adult (Figure 3EF). NF-L and NF-M were exclusively found in nerve fibres at stage 40; NF-L immunoreactivity was than faintly present therein to stage 44, while NF-M 
immunoreactivity persisted with similar intensity to the end of metamorphosis and in the adult frog (see also Figure 3B). NF-H immunoreactivity was absent in tadpoles as well as in the adult.

\section{NIF proteins in the fungiform papilla of the tongue of the adult frog (Table 4; Figure 3)}

In the fully developed fungiform papillae nerve fibres in the connective tissue core and the subepithelial plexus showed the presence of NF-M and peripherin. NF-L and NF-H were expressed in a few cells placed at the base of the neuroepithelium; their body was peripherally placed and showed immunostained prolongements directed to the centre of the taste disc.

\section{Discussion}

Results of immunohistochemical investigation of NIF proteins expression in the tongue of metamorphosing tadpoles and adult individuals of Rana esculenta demonstrate the following points:

(i) peripherin, NF-L and NF-M are expressed in nerve trunks as well as sub- and intraepithelial nerve fibres at early stages of development and persist therein in the adult; however, peripherin and NF-M are only found in nerve fibres outside the sensory epithelium in adult individuals;

(ii) some epithelial cells express peripherin in the early developing tongue; NF-L and NF-H are found in basally located cells of the taste disc in the adult frog.

Previous investigations of the distribution of NIF proteins in the taste organ mainly concerned higher vertebrates and results were sparse and not consistent. In the human, Witt and Reutter (1998) showed the presence of NF-H in nerve fibres reaching the primordia of taste buds from the eighth postovulatory week, with NF-L immunoreactivity appearing therein by the 11th week. On the other hand, Yoshie
Table 2. Neuronal intermediate filaments expression in nerves of the body of the tongue during metamorphosis and in adult frog.

\begin{tabular}{|c|c|c|c|c|c|c|c|}
\hline \multirow[b]{2}{*}{ Neurofilament protein } & \multicolumn{6}{|c|}{ Tadpole Developmental Stage } & \multirow{2}{*}{ Adult } \\
\hline & 38 & 40 & 41 & 43 & 44 & 45 & \\
\hline NF-L & - & + & + & + & + & + & + \\
\hline NF-M & + & ++ & ++ & ++ & + & + & + \\
\hline NF-H & - & - & - & - & - & - & - \\
\hline Peripherin & + & ++ & ++ & + & + & + & + \\
\hline
\end{tabular}

not labeled; + labeled; ++ strongly labeled

Table 4. Neuronal intermediate filaments expression in the fungiform papilla of adult frogs.

\begin{tabular}{lccc}
\hline \hline Neurofilament & $\begin{array}{c}\text { Fibres in the connective } \\
\text { tissue }\end{array}$ & $\begin{array}{c}\text { Subepithelial } \\
\text { plexus }\end{array}$ & $\begin{array}{c}\text { Basal cells of } \\
\text { the taste disc }\end{array}$ \\
NF-L & - & - & + \\
NF-M & ++ & ++ & - \\
NF-H & - & - & ++ \\
Peripherin & + & + & - \\
\hline
\end{tabular}

-not labelled; +labelled; ++ strongly labelled

et al. (1989) were unable to demonstrate immunoreactivity for NF-P (145 kDa, = NF-M) in taste bud cells and intraepithelial nerve fibres of the guinea pig, rat, mouse and cat; however, NF-P immunoreactivity was found by Yamamoto et al. (1997) in intragemmal fibres of taste buds of canine larynx as well as in the subgemmal plexus and in the vicinity of taste buds (perigemmal fibres), but not in taste bud cells. As far as anuran are concerned, Kuramoto (1988) found that in the bullfrog, Rana catesbeiana, NFP (150 kDa) immunoreactivity was present in thick fibres of nerve bundles ascending within the stalk of fungiform papillae; NFP immunoreactivity was also found in a plexus under the taste epitheli-

Table 3. Neuronal intermediate filaments expression in epithelial cells and sub/intraepithelial nerve fibres of the tongue of metamorphosing tadpoles.

\begin{tabular}{|c|c|c|c|c|c|c|c|c|c|c|c|c|}
\hline \multirow[b]{3}{*}{ Neurofilament } & \multicolumn{12}{|c|}{ Tadpole Developmental Stage } \\
\hline & \multicolumn{2}{|c|}{38} & \multicolumn{2}{|c|}{40} & \multicolumn{2}{|c|}{41} & \multicolumn{2}{|c|}{43} & \multicolumn{2}{|c|}{44} & \multicolumn{2}{|c|}{45} \\
\hline & Cells & Fibers & Cells & Fibers & Cells & Fibers & Cells & Fibers & Cells & Fibers & Cells & Fibers \\
\hline NF-L & - & - & - & + & - & \pm & - & \pm & - & \pm & - & - \\
\hline NF-M & - & - & - & + & - & + & - & + & - & + & - & + \\
\hline NF-H & - & - & - & - & - & - & - & - & - & - & - & - \\
\hline
\end{tabular}

-not labeled; \pm faintly labeled; + labeled. 

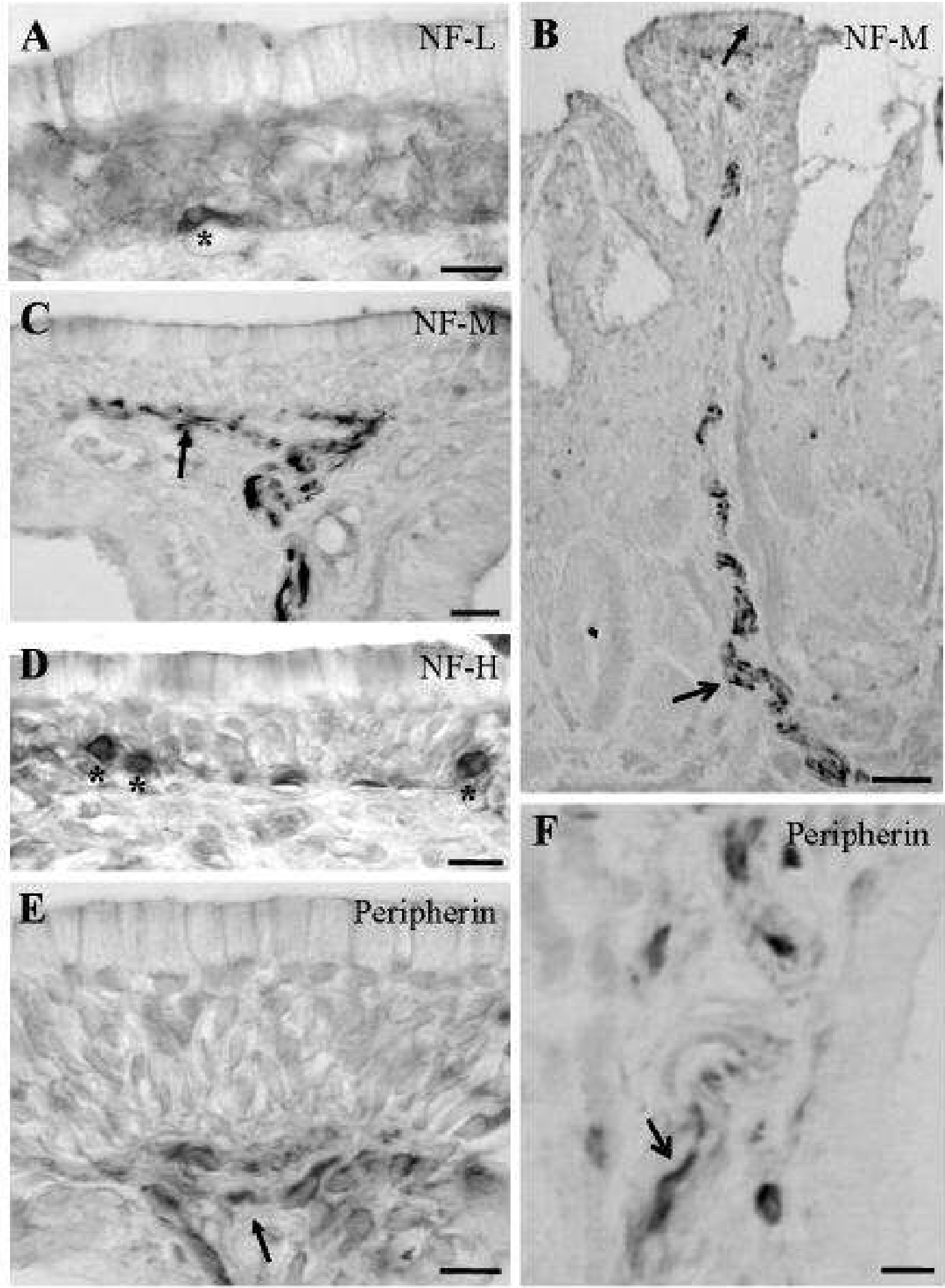

Figure 3. Expression of neuronal intermediate filaments in the fungiform papilla of adult Rana esculenta. NF-L, NF-M and NF-H, antibody to the light- medium- and high molecular weight subunit of filament triplet used for immunostaining. Open arrow, immunoreactivity in nerve trunk; filled arrow, immunoreactivity in the subepithelial nerve plexus; asterisk, immunoreactive basal cell in the sensory epithelium. See also Table 4. Scale bar: A, C-E, $10 \mu \mathrm{m} ; \mathrm{B}, 60 \mu \mathrm{m} ; \mathrm{F}, 20 \mu \mathrm{m}$. 
um and in a few horizontally running intraepithelial fibres. No immunoreactivity was found in taste bud cells. Therefore, the present study is the first systematic investigation of NIF proteins expression in vertebrate taste organ during development and in the adult individual.

In tadpoles, we showed that several NIF proteins are timely expressed in nerve fibres close to the differentiating sensory epithelium (Table 3) with peripherin appearing before NF-L and NF-M, whereas NF-H immunoreactivity was always absent. This finding is supported by a large body of evidence (Kaplan et al. 1990; Zhao et al. 1997; reviewed in Grant, Pant 2000) showing that NIF proteins are sequentially expressed during neurogenesis, NF-H appearing as the last one. Peripherin correlates with the outgrowth of central and peripheral neuronal populations (Troy et al. 1990b), but it can persist in the adult axonal cytoskeleton (Rhrich-Haddout et al. 1997) and is also found in regenerating adult neurones of the dorsal root ganglia (Wong et al. 1990). Instead, NF-H is expressed in brain and spinal cord neurones as the cytoskeleton is stabilised (Willard et al. 1983; Carden et al. 1987). Therefore, our data suggest that neurones innervating the frog's taste organs maintain some plasticity in their cytoskeleton even in the adult.

An intriguing finding of this work is that clusters of peripherin-immunoreactive cells are present in the tongue epithelium (possibly in the taste disc anlage) as early as stage 38 at site where nerve fibres approach the surface (Figure 2D); moreover, cells expressing NF-L and NF-H were found in basal position in the taste disc of adult frogs and they showed the typical shape and position of basal cell (Sbarbati et al. 1988). Therefore, cells expressing NIF proteins that are markers of developing and mature neurones are sequentially present in the taste epithelium. This suggests that neuronal-like cells are present in the differentiating tongue epithelium to persist in the adult taste organ. Such a suggestion is supported by the findings of Toyoshima et al. (1999) showing the presence of non-innervated, serotonin-containing Merkel cells in the undifferentiated tongue epithelium of the bullfrog, Rana catesbeiana; later on in development, these cells become innervated and assume the position of basal cells in the mature taste disc. Interestingly, the presence of NIF proteins in subsets of epithelial cells is confirmed by findings in mammals: Fantini et al. (1995) and Narisawa et al. (1994) found immunoreactivity for neurofilaments and NF-H, respectively, in Merkel cells of the human skin and Pasche et al. (1990) showed immunoreactivity for neurofilaments in Merkel cells of the mouse embryonic epidermis before nerve contact; moreover, Baudoin et al. (1993) showed the presence of peripherin and NF-L in neuroendocrine carcinomas of the human skin. Therefore, neuronal-like cells of the frog tongue epithelium could be involved in the differentiation/function of the taste organ.

\section{Acknowledgments}

This work was performed in the frame of a PolishItalian Scientific and Technological Cooperation Joint Project, which gave support to the mobility of researchers. The financial support from DWZUJ/KBN/2001-2002 to K.Z. and the University of Verona (ex $60 \%$ funds) to C.Z. is gratefully acknowledged.

\section{References}

Baudoin C, Meneguzzi G, Portier M M, Bernerd F, Pisani A, Ortonne JP. Peripherin, a neuronal intermediate protein, is stably expressed by neuroendocrine carcinomas of the skin, their xenograft on nude mice, and the corresponding primary cultures. Cancer Res 1993;53:117587.

Carden MJ, Trojanowski JQ, Schlaepfer WW, Lee VM. Two-stage expression of neurofilament polypeptides during rat neurogenesis with early establishment of adult phosphorylation patterns. J Neurosci 1987; 7:3489-04

Chou HC, Chien CL, Lu KS. The distribution of PGP9. 5, BDNF and NGF in the vallate papilla of adult and developing mice. Anat Embryol (Berl) 2001;204:161-9.

Fantini F, Johansson 0 . Neurochemical markers in human cutaneous Merkel cells. An immunohistochemical investigation. Exp Dermatol 1995;4:365-71.

Gervasi C, Stewart CB, Szaro BG. Xenopus laevis peripherin (XIF3) is expressed in radial glia and proliferating neural epithelial cells as well as in neurons. J Comp Neurol 2000;423:512-31.

Gioglio L, Rapuzzi G, Dell'Orbo C. Fine structure of the fungiform papilla in a ranid frog (Rana esculenta). J Morphol 1988;195:1-16.

Gosner KL. A simplified table for staging anuran embryos and larvae with notes on identification. Herpetologica 1960;16:183-90.

Grant P, Pant HC. Neurofilament protein synthesis and phosphorylation. J Neurocytol 2000;29:843-72.

Kaplan MP, Chin SSM, Fliegner KH, Liem RKH. $\alpha$-internexin, a novel neuronal intermediate filament protein, precedes the low molecular weight neurofilament protein (NF-L) in the developing brain. $J$ Neurosci 1990;10:2735-48.

Kuramoto H. An immunohistochemical study of cellular and nervous elements in the taste organ of the bullfrog, Rana catesbeiana. Arch Histol Cytol 1988;51:205-21.

Kusakabe T, Matsuda H, Kawakami T, Syoui N, Kurihara K, Takenaka T, et al. Ontogeny of regulatory neuropeptides in the bullfrog taste organ. Dev Brain Res 1996;96:285-89.

Lasek RJ, Phillips L, Katz MJ, Autilio-Gambetti L. Function and evolution of neurofilament protein. Ann NY Acad Sci 1985;455:462-78.

Mencarelli C, Bugnoli M, Contorni M, Moscatelli A, Ruggiero P, Pallini $V$. Phosphorylated epitopes of neurofilaments have been conserved during chordate evolution. Biochem Biophys Res Comm 1987; 149: 807-14.

Narisawa $Y$, Hashimoto $K$, Kohda H. Immunohistochemical demonstration of the expression of neurofilament proteins in Merkel cells. Acta Dermato-Venereologica 1994; 74:441-43. 
Nomura S, Shiba Y, Muneoka Y, Kanno Y. A scanning and transmission electron microscope study of the premetamorphic papillae: possible chemoreceptive organs in the oral cavity of an anuran tadpole (Rana japonica). Arch Histol Jpn 1979a;42:507-16.

Nomura S, Shiba Y, Muneoka Y, Kanno Y. Developmental changes of premetamorphic and fungiform papillae of the frog (Rana japonica) during metamorphosis: a scanning electron microscopy. Hiroshima J Med Sci 1979b;28:79-86.

Osculati F, Sbarbati A. The frog taste disc: a prototype of the vertebrate gustatory organ. Prog Neurobiol 1995;46:351-99.

Pasche F, Merot $Y$, Carraux P, Saurat JH. Relationship between Merkel cells and nerve endings during embryogenesis in the mouse epidermis. J Invest Dermatol 1990;95:247-51.

Portier MM, de Nechaud B, Gros F. Peripherin, a new member of the intermediate filament protein family. Dev Neurosci 1983; 6:335-44.

Rhrich-Haddout F, Klosen P, Portier MM, Horvat JC. Expression of peripherin, NADPH-diaphorase and NOS in the adult rat neocortex. Neuroreport 1997;8:3313-26.

Sbarbati A, Franceschini F, Zancanaro C, Cecchini T, Ciaroni S, Osculati $F$. The fine morphology of the basal cell in the frog's taste organ. $J$ Submicrosc Cytol Pathol 1988;20:73-9.

Sbarbati A, Zancanaro C, Ferrara P, Franceschini F, Accordini C, Osculati F. Freeze-fracture characterization of cell types at the surface of the taste organ of the frog, Rana esculenta. J Neurocytol 1993;2:118-27.

Shecket G, Lasek RJ. Preparation of neurofilament protein from guinea pig peripheral nerve and spinal cord. J Neurochem 1980;35:133544.

Shaw G, Debus E, Weber K. The immunological relatedness of neurofilament proteins of higher vertebrates. Eur J Cell Biol 1984;34:13036.

Szaro BG, Gainer H. Identities, antigenic developments, and topographic distributions of neurofilament proteins in the nervous systems of adult frogs and tadpoles of Xenopus laevis. J Comp Neurol 1988; 273:344-58.

Szaro BG, Lee VM, Gainer H. Spatial and temporal expression of phosphorylated and non-phosphorylated forms of neurofilament proteins in the developing nervous system of Xenopus laevis. Dev Brain Res 1989;48:87-03.

Toyoshima K, Shimamura A. An immunohistochemical demonstration of neuron-specific enolase in the Merkel cells of the frog taste organ. Arch Histol Cytol 1988;51:295-97.

Toyoshima K, Seta Y, Toyono T, Takeda S. Merkel cells are responsible for the initiation of taste organ morphogenesis in the frog. J Comp Neurol 1999;406:129-40.

Troy CM, Brown K, Greene LA, Shelanski ML. Ontogeny of the neuronal intermediate filament protein, peripherin, in the mouse embryo. Neuroscience 1990;36:217-37.

Troy CM, Muma NA, Greene LA, Price DL, Shelanski ML. Regulation of peripherin and neurofilament expression in regenerating rat motor neurons. Brain Res 1990b;529:232-8.

Wakisaka S, Miyawaki Y, Youn SH, Kato J, Kurisu K. Protein gene-product 9.5 in developing mouse circumvallate papilla: comparison with neuron-specific enolase and calcitonin gene-related peptide. Anat Embryol (Berl) 1996;194:365-72.
Walker JH, Boustead CM, Witzemann V, Shaw G, Weber K, Osborn M. Cytoskeletal proteins at the cholinergic synapse: distribution of desmin, actin, fodrin, neurofilaments, and tubulin in Torpedo electric organ. Eur J Cell Biol 1985;38:123-33.

Willard M, Simon C. Modulations of neurofilament axonal transport during the development of rabbit retinal ganglion cells. Cell 1983; 35:551-9.

Witt M. Ultrastructure of the taste disc in the red-bellied toad Bombina orientalis (Discoglossidae, Salientia). Cell Tissue Res 1993;272:5970.

Witt M, Reutter K. Innervation of developing human taste buds. An immunohistochemical study. Histochem Cell Biol 1998;109:281-91.

Witt M, Reutter K, Ganchrow D, Ganchrow JR. Fingerprinting taste buds: intermediate filaments and their implication for taste bud formation. Philos Trans R Soc Lond B Biol Sci 2000;355:1233-37.

Wong J, Oblinger MM. Differential regulation of peripherin and neurofilament gene expression in regenerating rat DRG neurons. J Neurosci Res 1990;27:332-41.

Yamamoto Y, Hosono I, Atoji Y, Suzuki Y. Morphological study of the vagal afferent nerve endings in the laryngeal mucosa of the dog. Anat Anz 1997;179:65-73.

Yoshie S, Teraki Y, Iwanaga T, Fujita T. Immunocytochemistry of neuronspecific proteins and neuropeptides in taste buds and associated nerves. Arch Histol Cytol 1989; Suppl 1:389-96.

Zancanaro C, Sbarbati A, Franceschini F, Balercia G, Osculati F. The chemoreceptor surface of the taste organ in frog, Rana esculenta. An ultrastructural study with lantanum nitrate. Histochem J 1990; 22: 480-6.

Zhao Y, Szaro BG. Xefiltin, a Xenopus laevis neuronal intermediate filament protein, is expressed in actively groving optic axons during development and regeneration. J Neurobiol 1997; 33:811-24.

Zuwala K. Developmental changes in the structure of mucouse membrane in oral cavity and taste organs in tadpoles of the frog, Rana temporaria (SEM). Acta Biol Cracov Ser Zool 1991;33:60-8.

Zuwala K. The development of the tongue and morphological and cytological changes in taste discs of Rana esculenta. J Submicrosc Cytol Pathol 2002a; 34:17-25.

Zuwala K. Developmental of tongue and taste disks of Pelobates fuscus. Folia Biol 2002b;50:165-72.

Zuwala K, Jakubowski M. Development of taste organs in Rana temporaria: transmission and scanning electron microscopic study. Anat Embryol 1991;184:363-9.

Zuwala K, Jakubowski M. The lining of oro-pharyngeal cavity and it's taste organs in the development of Bufo bufo tadpoles, the common toad. Acta Biol Cracov, ser zool 1997;39:87-93.

Zuwala K, Jakubowski M. Taste Organs in Lower Vertebrates. Morphology of the Taste Organs in Amphibia. Dutta HM, Datta Munshi JS, eds. Vertebrate Functional Morphology: horizon of research in the 21 century. Science Publishers, Inc, Enfield (NH), USA, Plymouth, UK, 2000, p. 221-39.

Zuwala K, Kato S, Jakubowski M. Two generations of the tongue and gustatory organs in the development of Hynobius dunni Tago. J Anat 2002;201:91-7. 